Open Access

\title{
The social pillar of sustainability: a quantitative approach at the farm level
}

\author{
Anna Gaviglio ${ }^{*}$, Mattia Bertocchi, Maria Elena Marescotti, Eugenio Demartini and Alberto Pirani
}

\author{
* Correspondence: \\ anna.gaviglio@unimi.it \\ Department of Health, Animal \\ Science and Food Safety, University \\ of Milan, Via Celoria 2, 20133 \\ Milano, Italy
}

\begin{abstract}
The present research proposes a model for the assessment of the social pillar of sustainability at the farm scale. Contrary to what is available for the environmental and economic pillars, there is a considerable lack of exhaustive approaches able to evaluate the social dimension of sustainability in rural areas. Thus, the idea was to create a mean by which a quantitative evaluation of the social characteristics of farms could be made. The study involved farms of the South Milan Agricultural Park, located in northern Italy. Thirty sampled farms were selected in order to represent the different livestock systems, land areas, economic dimensions and levels of multifunctionality of the area. The framework is based on a set of 15 indicators able to evaluate five main social "components": (i) quality of the products and the region, (ii) short supply chain and related activities, (iii) work, (iv) ethical and human development and (v) society, culture and ecology. The work was structured using the following steps: identification of the relevant variables for the social sustainability of farms, determination of the framework of indicators, assignment of their range scores, data collection, calculation of the score for each farm, data analysis and visualization. The method allows different types of analysis in relation to the objective of the research. Three main approaches were individuated: (1) the comparison among farms is the "farms' ranking" and the "aggregate ranking"; (2) the evaluation of single themes of sustainability is the "single indicator evaluation" approach and (3) the temporal comparison of the farm's result is the "score evolution" approach. The method showed a high sensitivity to the multifunctionality and the type of farm production, especially organic vs conventional, while other characteristics, such as the type of livestock and the land area, seem to differentiate the sample less or to characterize it in only a few social components. The work has underlined the importance and the advancement in the study of the social dimension that, however, needs further in-depth analysis through comparison with the other two pillars and among various social states in different rural areas.
\end{abstract}

Keywords: Social sustainability, Agricultural sustainability, Indicators, Farm performance, Multi-attribute analysis

\section{Background}

Over the past 30 years, interest in the evaluation of agricultural activities' sustainability has grown considerably, many studies have been proposed and several assessment methods developed. The literature offers approaches at different spatial scales, ranging 
from field and farm to regional, national, and even international scale (Jacobs 1995, Hansen 1996, Smith and McDonald 1998). Researchers that opted for a farm/local scale in their studies (Van der Werf and Petit 2002, Häni et al. 2003, Pacini et al. 2004, Rasul and Thapa 2004, Van Cauwenbergh et al. 2007, Meul et al. 2008, Vilain 2008, Gómez-Limón and Riesgo 2009, Reig-Martinez et al. 2011, Paracchini et al. 2015, Thiollet-Scholtus and Bockstaller 2015) took advantage of the possibility of an in-depth investigation of farm dynamics, while research studies that used a regional/territorial scale (Paracchini et al. 2011, Mazzocchi et al. 2013, Demartini et al. 2015) could limit the cost of analysis, ensuring transparency of data and repeatability of measurements (Demartini et al. 2015).

Although the environmental, social and economic pillars of sustainability are linked to each other, a single integrated approach seems to be difficult (Wells 2001, Zimmerer and Basset 2003). This reflects problems of data requirement and incommensurability between different facets or dimensions of sustainability that become stronger as the analysis moves to the system beyond the farm boundaries (Rigby et al. 2001). As a result, research studies tend to include these three pillars in their studies, treating them separately or with a different relevance (Singh et al. 2009). Furthermore, the different pillars have attracted varying levels of attention.

The environmental assessment is more studied, because of the growing social sensitivity of the community to ecological issues, and therefore, many approaches have been discussed and developed and researchers have multiple analytical opportunities. On the other hand, the evaluation of economic and, especially, social sustainability suffers from a lack of accepted and well-grounded frameworks (Chatzinikolaou and Manos 2012).

Although contemporary society recognizes agriculture as having an important responsibility in safeguarding the region, its culture and traditions (Gaviglio et al. 2014a), the measurement of social sustainability seems to be less studied. Moreover, most of the approaches that seek to involve a complete evaluation of the sustainability use qualitative assessments of the social pillar, based on observations and opinions or indicators that require difficult to find data (see Häni et al. 2003, Van Cauwenbergh et al. 2007, Meul et al. 2008, Vilain 2008).

As a matter of fact, finding a match between the social sustainability objectives and their corresponding indicators is a challenging task. According to Omann and Spangenberg (2002), this assessment concerns some relevant problems. Firstly, the perception of social issues is heterogeneous in different territorial contexts and this causes a lack of conceptual clarity. Secondly, when scientists suggest a great number of social indicators they still hesitate to formulate normative targets. Thus, the complexity of the concept might not be manageable in the current institutional settings. All this considered, the assessment of social sustainability seems to be particularly dependent on the local context and the sociopolitical goals proposed by policy-makers (Littig and Griessier 2005). Thus, the choice of indicators used in the analysis probably represents the most critical step of the research. Particularly, the scientific literature underlines the importance of the balance between a validated approach, reliability and significance of the indicators and the objectives to be achieved (Girardin et al. 1999), under the constraints of data availability. 
The aim of this paper is to present a method for the evaluation of social sustainability of farms that uses quantitative indicators. The framework consists of 15 indicators able to assess the social performances of the farms that could have relevant reflection on their role for the rural area. The method offers useful easy-to-read results for farmers, decision-makers and researchers. Furthermore, a wide selection of indicators is presented which seems to represent a good (if not exhaustive) review that could be useful for further studies on this theme.

The remainder of the text is organized into three sections. The "Methods" section presents the features of the method: the approach to the social evaluation, the framework, its indicators and the case study. The "Results" section presents the results and their discussion. Finally, a concluding paragraph offers a summary of the research and some reflections on its potentialities and limitations.

\section{Methods}

\section{Framework}

The present method aims at the assessment of social sustainability at farm level using quantitative indicators. It is worth noting that the proposed approach excludes the evaluation of some social dimension that could be described by qualitative analysis; nonetheless, the definition of a system of quantitative measures allows researchers and farmers for direct comparisons between themes and farms that would not be possible otherwise.

Table 1 and Fig. 1, respectively, summarize the indicators used in the method and the component derived, and provide a brief idea of the framework adopted (in-depth details are available in Appendix).

The choice of indicators is based on the literature review, even if the lack of a shared framework for the social assessment at the farm scale often forces the researchers to an arbitrary choice of indicators (Van Cauwenbergh et al. 2007). The

Table 1 Social sustainability indicators and components used in the analysis

\begin{tabular}{llllll}
\hline Code & Indicator & Max score & Code & Component & Max score \\
\hline S_1 & Quality of the products & 20 & CS_1 & $\begin{array}{l}\text { Quality of the products } \\
\text { and the region }\end{array}$ & 50 \\
S_2 & Rural buildings & 12 & & & \\
S_3 & Landscape and territory & 18 & & & \\
S_4 & Short food supply chain & 30 & CS_2 & $\begin{array}{l}\text { Short food supply chain } \\
\text { and related activities }\end{array}$ & 50 \\
S_5 & Related activities & 20 & & Work & 50 \\
S_6 & Work & 25 & CS_3 & Work & \\
S_7 & Sustainability of the employment & 15 & & & 50 \\
S_8 & Training & 10 & & & \\
S_9 & Livestock management & 25 & CS_4 & Ethical and human \\
S_10 & Associations and social implications & 15 & & development & \\
S_11 & Cooperation & 10 & & & \\
S_12 & Waste management & 15 & CS_5 & Society, culture \\
S_13 & Accessibility to the farm spaces & 10 & & and ecology & \\
S_14 & Sustainable use of materials & 15 & & & \\
S_15 & Education & 10 & & & \\
\hline
\end{tabular}




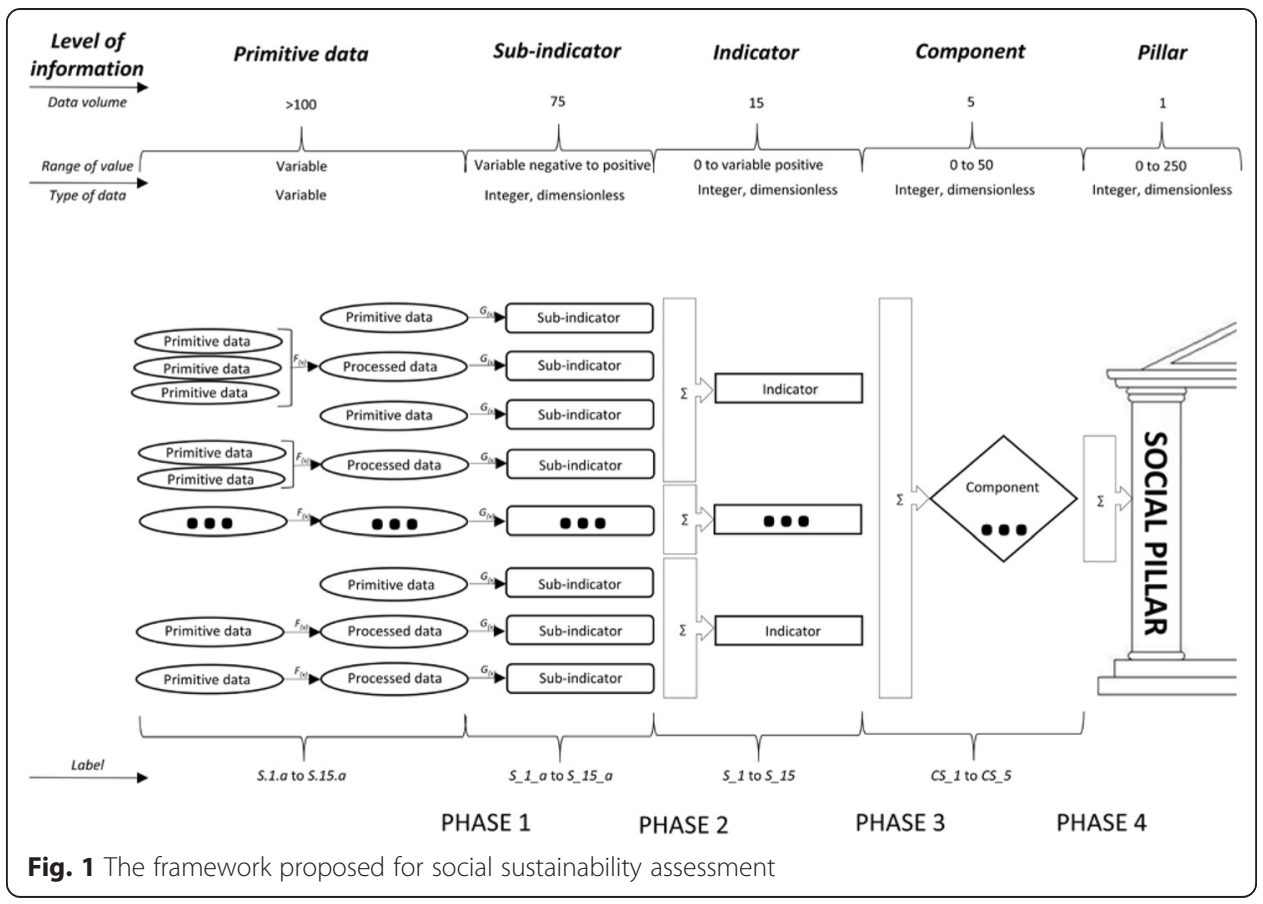

selection process was carried out through the collection of the indicators detected from currently available methods. Among these, the choice was based on a combination of the best characteristics of simplicity, data requirements and significance for the case study.

The following components of agricultural activities were observed, considering their social dimension (Table 1$)$ : $\left(C S \_1\right)$ the products and regional management; $\left(C S \_2\right)$ the short food supply chain and related activities; (CS_3) employment and working conditions; (CS_4) the ethical and human development about animal welfare and the cooperation and association; and (CS_5) cultural and ecological themes. Note that the evaluation of these components involves the main social themes of the agricultural activities; nevertheless, some topics reported in the literature are not treated in order to avoid the use of qualitative indicators of data. In particular, we refer to food hygiene and safety and quality of life. ${ }^{1}$

In the proposed method, the measurements of farm characteristics are converted into dimensionless values that represent an easy-to-read score of the raw data according to the desirability of the measured performance. For example, when measuring the indicator "S_1 Quality of the products" higher scores rationally correspond to higher measures. Furthermore, each indicator can range from a minimum or a maximum score (single scores are reported in Appendix); while the minimum score is always zero, the maximum scores vary depending on the social relevance attributed to the indicator, and therefore, more relevant indicators have higher maximum scores. This weighting procedure derived from a subjective evaluation typical of these types of studies that assigned the scores in accordance to the relevance attributed by the literature (when available) and the characteristics of the case study and its objectives (von Wirén_Lehr 2001). This process, which is convenient for adaptation to the local 
context, involves the typical risks connected to subjective norms. In order to reduce this possible source of errors, some studies used the principle of equality among the indicators (Meul et al. 2008); nonetheless, other studies argue that indicators cannot be considered equally relevant with reference to sustainability assessment (Vilain 2008, Zahm et al. 2008). In this sense, researchers should be aware of the trade-off between the two options and carefully adopt the one that they consider the best in the research context.

The method is characterized by an aggregative structure (Fig. 1) aimed at reducing data from farm characteristics to a unique value of the social pillar. As shown in Fig. 1, the process is divided into four basic phases:

- Phase 1: collection and analysis $\left(\mathrm{F}_{(\mathrm{x})}\right.$ and $\left.\mathrm{G}_{(\mathrm{x})}\right)$ of the farms' characteristics, classified from S.1.a to S.15.a, in order to obtain a raw data set;

- Phase 2: elaboration of 75 sub-indicators, classified from $S \_1 \_a$ to $S \_15 \_a$, leads to integer and dimensionless values that range from negative to positive values, according to their maximum scores;

- Phase 3: calculation of the 15 indicators, classified from $S_{-} 1$ to $S_{-} 15$, reported in Table 1, obtained through the sum of two or more sub-indicators. A minimum [0] and a maximum [variable] score is applied depending on the case (see Appendix);

- Phase 4: the sum of two or more indicators provides the value of five components of the social sustainability pillar, classified from CS_1 to CS_5. A minimum [0] and a maximum [50] score is applied. In turn, the sum of the components leads to the overall value of the social dimension of sustainability, which can range from 0 to 250 .

\section{The components}

In the following sections, we describe the indicators listed in Table 1, classified by component.

\section{Component 1 (CS_1): quality of the products and the region}

The social inclusion of rural areas highly depends on the connection between them and the citizenship. One of the most important means is the consumers' perception of the farm's products. Often people assign good environmental standards to high-quality products that contribute to a higher social acceptance of the agriculture and its production systems.

There are wide ranges of categories of consumers, defined as ethical consumers or citizen-consumers, who associate a very high value to the attribute of the quality of the product and the region where they are produced. Among these products, the CS_1 component identified two main categories: quality-certified commodities and food products $\left(S \_1 \_a\right.$ and $\left.S \_1 \_b\right)$ and organic products $\left(S \_1 \_c\right.$ and $S_{-}{ }_{-} d$ ).

In the first case, the literature review on consumers' perceptions shows some social relation between protected denomination of origin (PDO) products and the attributes of support in order to sustain regional manufacturers (Van Ittersum et al. 2007, Verbeke et al. 2012) and to contribute to the survival of the social identity 
of the region (Vilain 2008). Thus, nowadays, these recent purchasing motivations are assigned a comparable importance with the typical attributes such as high standards (Van Ittersum et al. 2007), the tradition (Verlegh and Steenkamp 1999, Dimara and Skuras 2003), the taste (Platania and Privitera 2006, Vanhonacker et al. 2010) and food safety (Dimara and Skuras 2003).

Regarding organic food consumption, many researches stated the importance of the socio-economic traits of consumers (Hamm and Gronefeld 2004, Falguera et al. 2012), in particular tradition (Chinnici et al. 2002) and animal welfare (Magnusson et al. 2003, Makatouni 2002). In this case too, these attributes seem to have a primary relevance, besides those historically associated with organic consumption: first of all, environmentally friendly behaviour and also, as stated by some recent studies, the importance of the intrinsic attributes of the products (Gaviglio and Pirani 2015a), such as the healthiness (Pieniak et al. 2010), the high quality (Chinnici et al. 2002) and the taste (Fotopoulos and Krystallis 2002, Zanoli and Naspetti 2002, Kihlberg and Risvik 2007).

While the establishment of organic and labelled products is easy because of certification, there is a wide range of attempts to define local products (Hand and Martinez 2010). Because of the difficulties in defining the standard of quality of products without certification, this component only considers labelled products. The evaluation of local and typical products is treated by the CS_2 component, without taking into account the attribute of their quality.

Finally, conscious social behaviour also involves issues not closely linked to the products, such as the functional and aesthetic roles of rural buildings ( _ 2$)_{2}$ and the farm landscape (S_3). These are important features that characterize the architecture (Meul et al. 2008) and they represent positive or negative externalities in the social acceptance of rural areas (Van Cauwenbergh et al. 2007).

\section{Component 2 (CS_2): short food supply chain and related activities}

Among the most important motivations in buying local products, the literature found some social attributes such as tradition (Bessiére 1998), supporting local economies and trust in producers (Seyfang 2006, Lockie 2009). These are indicated by consumers as relevant means able to connect the citizenship with the countryside.

Selling products through short chain systems involves different types of opportunities, such as direct sales $\left(S_{-} 4_{-} a, S_{-} 4 \_c\right.$ and $\left.S_{-} 4 \_d\right)$, online sales $\left(S_{-} 4 \_b\right)$, ethical purchasing groups $\left(S_{-} 4 \_e\right)$, farmers' markets $\left(S_{-} 4_{-} f\right)$, restaurants and shops $\left(S_{-} 4_{-} g\right)$ and canteens $\left(S_{-} 4 \_h\right)$. The direct sales formula is mainly dedicated to local products and creates a close relationship between producers and consumers that cannot be explained just within an economic rationality (Gaviglio et al. 2015b).

The implications on other activities besides the agricultural production, such as the maintenance and management of public spaces and resources $\left(S \_5 \_a\right)$, related activities like agritourism, restaurants, bed and breakfast $\left(S \_5 \_b\right)$ and educational farms $\left(S \_5 \_c\right.$ and $\left.S \_5 \_d\right)$ are other important means of linking the town and the countryside (Vilain 2008). Citizens often use these systems to get to know the rural world and to learn about production processes and agro-food systems (Santini and Paloma 2013). 
Component 3 (CS_3): work

Employment in the agriculture sector has fallen considerably in the last decades; therefore, the maintenance of a sustainable level of employment $\left(S_{-} 7\right)$ is relevant for the social and economic development (S_6) of the agricultural area (Häni et al. 2003, Meul et al. 2008, Vilain 2008, Gómez-Limón and Fernandez 2010, Reig-Martinez et al. 2011, Bonneau et al. 2014). In this context, training (S_8) is a key aspect for the growth of the agricultural sector (Vilain 2008) by which farms play a leading role in development and innovation because of the requirement for high-profile skilled jobs involved in related activities, research and breeding.

\section{Component 4 (CS_4): ethics and human development}

The human and ethical development of agriculture involves multiple issues. Among these, animal welfare is today a primary requirement of society (Fortun-Lamothe et al. 2009, Broom 2010). Livestock management involves animal health and the farm's ability to implement innovations in the agricultural sector. This is a very complex issue, and the use of a single approach able to evaluate different types of livestock is difficult. Therefore, the indicator $\left(S_{-} 9\right)$ is based on the diversification of the most common species of animals (cattle, pigs, poultry, sheep/goats) bred in the area. In this way, we only evaluated the management of the most important livestock of the farm (through the calculation of the LSU, "livestock units").

Cooperation and association are relevant instruments of innovation of agricultural systems (Vilain 2008) and they are important indicators of human development in rural areas. Among these factors, the social dynamism and vitality of an area heavily depend on membership in associations $\left(S_{-} 10 \_a\right.$ and $\left.S \_10 \_b\right)$, consortia $\left(S_{-} 10 \_c\right)$ and cooperation with other farms in the surrounding area in direct sales $\left(S_{-} 11 \_a\right.$ and $\left.S_{-} 11 \_b\right)$, agritourism activities $\left(S_{-} 11 \_c\right)$, the production structures $\left(S \_11 \_d\right)$ and the workforce $\left(S \_11 \_e\right)$.

\section{Component 5 (CS_5): society, culture and ecology}

The inclusion of rural areas involves the recognition of the ecological, cultural and social effort of farms in their production process. In this sense, the component takes into account four main aspects. A proper waste management through recycling processes $\left(S_{-} 12 \_a\right)$ and the use of recycled materials $\left(S_{-} 12 \_b, S_{-} 12 \_c\right.$ and $\left.S \_12 \_d\right)$ has a great environmental importance but it also involves the social acceptance of the agriculture systems. The farm's open spaces $\left(S_{-} 13 \_a\right.$ and $\left.S_{-} 13 \_b\right)$ have important recreational functions useful for the population of a rural area.

Moreover, a proper landscape management can be a relevant source of income for the multifunctional farm's activities (Vilain 2008). The agricultural production systems involve the use of materials, such as feed $\left(S_{-} 14 \_a\right)$, fertilizers $\left(S_{-} 14 \_b\right)$, water $\left(S_{-} 14 \_c\right)$ and seeds $\left(S \_14 \_e\right)$ that characterizes the sustainability of the farm management (Vilain 2008). A high dependence from the outset, even the buying of animals $\left(S \_14 \_c\right)$, often causes a reduction of autonomy in making production, marketing and management decisions. It also alters the resilience of the system and the ability to adapt to economic, environmental and social changes.

The educational level (S_15_a) of the farm personnel is important for the cultural and social growth of agricultural areas (Van Cauwenbergh et al. 2007). As found 
by Elfkih et al. 2012, there is a probable positive effect of educational level on the achievement of overall sustainability. The education of the workforce and the entrepreneur is also able to encourage openness to new knowledge and innovation in agriculture.

\section{Case study}

The survey was carried out on the region of the South Milan Agricultural Park. The park is an area located on the Po plain (northern Italy), in one of the most intensively agricultural regions in Europe (INEA 2014). This is an agricultural park that involves the peri-urban area around the city of Milan. It covers more than 40,000 ha of lowland where farms are characterized by intensive production systems, a wide range of land areas, livestock and economic dimensions. The main crops are maize, rice and grassland (Migliorini and Scaltriti 2012), while the main livestock are cattle, poultry and pigs. The high population density confers the typical attributes of peri-urban areas, such as fragmentation and high economic value of the land (Gaviglio et al. 2014b).

We carried out the sample stratification considering farm size, the main production and geographical location. The selection was also linked to the willingness of farmers to respond to interviews and to provide some administrative data (Briquel et al. 2001; Viglizzo et al. 2006).

Thirty farms with different breeding systems were selected: cattle (for milk or meat production), poultry, pigs, sheep and goats. Table 2 reports some of the main features of the sampled farms.

Data were collected using (i) interviews through questionnaire to farm personnel that provided an easy method to detect information, (ii) the Sistema Informativo Agricoltura Regione Lombardia (SIARL) database and (iii) estimations when not available from the other sources.

\section{Results}

The output of the method provides the values of each sub-indicator, indicator and component that contribute to the overall score of the social pillar. In relation to the objective of the research, the method still allows the use of different types of analysis.

\section{Farm comparison by ranking of indicators}

When the case study is focused on social sustainability aspects of individual farms, the method allows an in-depth analysis of farms through the evaluation of the basic indicators. Figure 2 shows a possible application of the results of two farms. Farm 1 has a conventional production system, the livestock are cattle for milk production and the land area is large. Farm 2 has the same characteristics but it also practises multifunctional activities, while farm 1 can be defined as non-multifunctional. These two farms are discussed as an example of how the method performs and how data can be interpreted to identify key actions to be adopted to improve farm performance. In general, farmers who have direct contact with consumers achieve higher social results that can also lead to higher environmental performance (Gafsi 
Table $\mathbf{2}$ Characteristics of the farms in the sample

\begin{tabular}{lll}
\hline Farm characteristic & Quantity N & Percentage \% \\
\hline Type of breeding & 7 & 23.33 \\
Bovine (meat prod.) & 15 & 50.00 \\
Bovine (milk prod.) & 4 & 13.33 \\
Poultry & 3 & 10.00 \\
Pigs & 1 & 3.33 \\
Sheep/goat & & \\
Land size-utilized agricultural area & 14 & 46.66 \\
$<50$ ha & 9 & 30.00 \\
$50-100$ ha & 7 & 23.33 \\
$>100$ ha & & 30.00 \\
Multifunctionality & 9 & 70.00 \\
Non-multifunctional & 21 & \\
Multifunctional & & 83.33 \\
Type of production & 25 & 16.66 \\
Conventional & 5 & 26.66 \\
Organic & 30 & 100.00 \\
Economic size-standard output (SO) & 13 & 43.33 \\
SO $<100$ & 9 & 30.00 \\
$100<$ SO $<300$ & & \\
SO $>300$ & 5 & \\
Total & & \\
\hline
\end{tabular}

and Favreau 2010). In our sample, farm 2 obtained higher scores in the CS_2, CS_3 and CS_5 components while farm 1 showed better scores in the CS_4 component. The short food supply chain related activities component result is a direct consequence of the different characteristics on multifunctionality. The third component underlined the higher contribution of multifunctionality to employment in the rural context. On the contrary, the other components seem to be less dependent on the multifunctionality level. Their scores are probably more influenced by other farm characteristics such as land area, type of production or the management choices of each farm. However, both farms could improve their sustainability level in the quality of the products and the region (CS_1) and work (CS_3). Farm 1 seems to show no interest in diversification of income and activities. Both farms showed high performance in ethical and human development (CS_4) and social, cultural and ecological sustainability (CS_5).

\section{Farm comparison by aggregate component ranking}

Radar diagrams are able to represent the overall performance of farms in the five components. This method is able to provide different approaches of farm ranking in relation to the sample features. The following figures show the farms' results, classified by livestock type (Fig. 3), land area (Fig. 4) and type of production (conventional vs organic) (Fig. 5). 


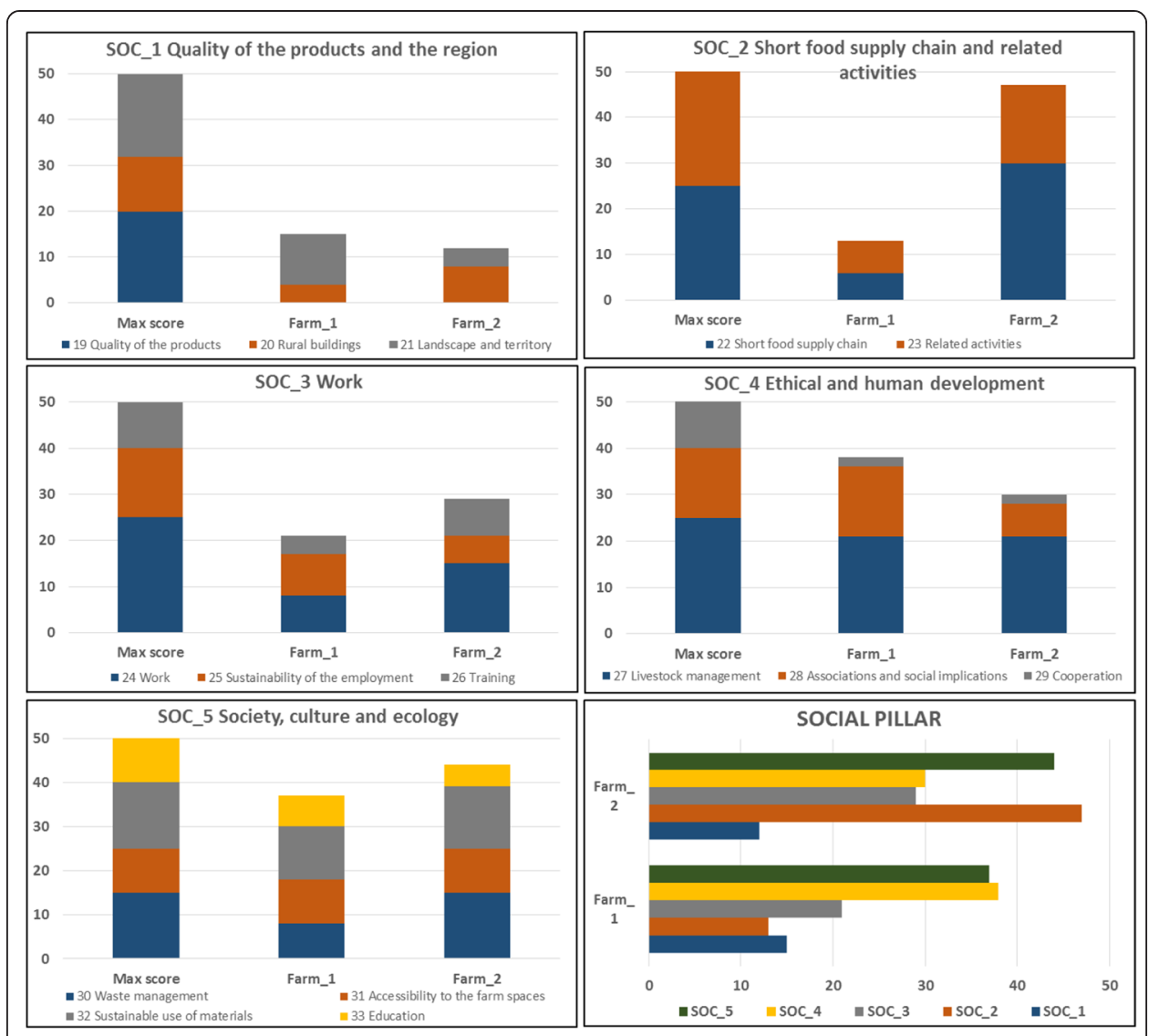

Fig. 2 Decomposition of the social pillar into five components and the related indicators for two cattle farms (milk production)

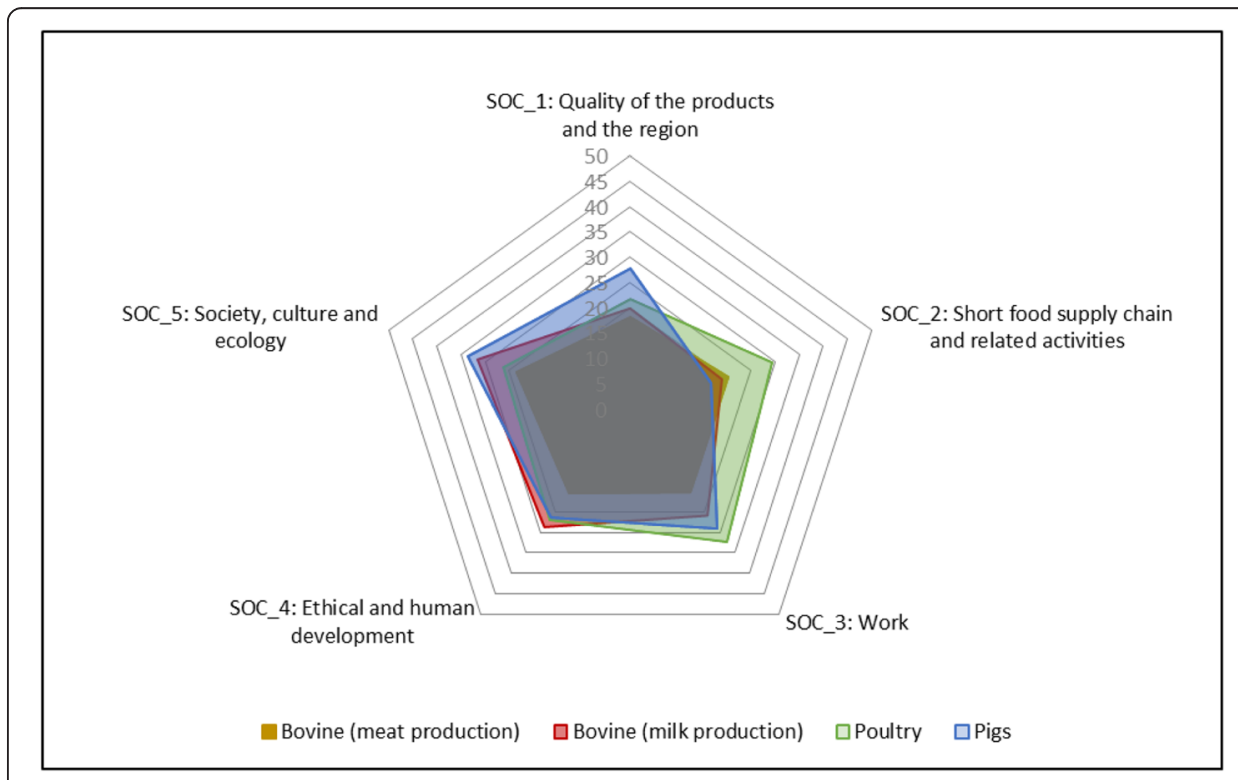

Fig. 3 Radar diagram of bovine (meat production) vs bovine (milk production) vs poultry vs pig farms' average performance 


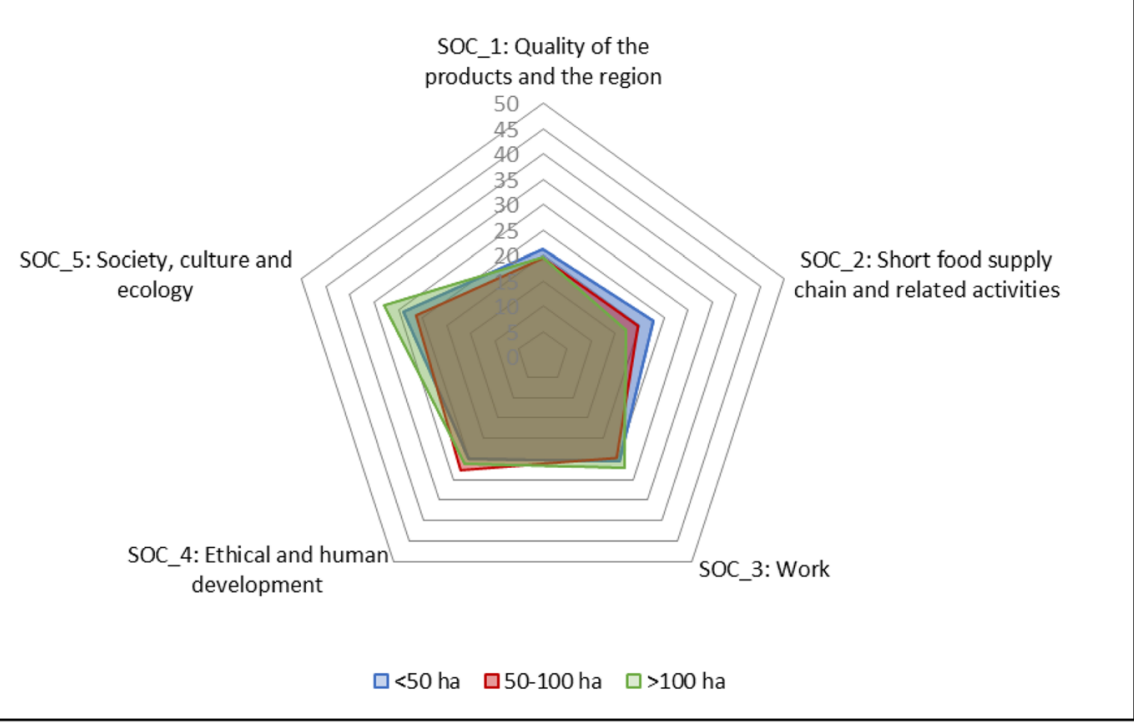

Fig. 4 Radar diagram of small (up to 50 ha) vs medium (50 to 100 ha) vs large (more than 100 ha) farms' average performance

In Fig. 3, the sample is divided into four categories of livestock type. Cattle farms (Fig. 3) showed generally lower values, in particular for meat production. These are often large farms that are not interested and do not have the necessary conditions to diversify production and to develop systems of short chain and related activities. In the CS_2 component (short food supply chain and related activities), they reached an overall score of 19 and 20, respectively, for milk and meat production, while poultry

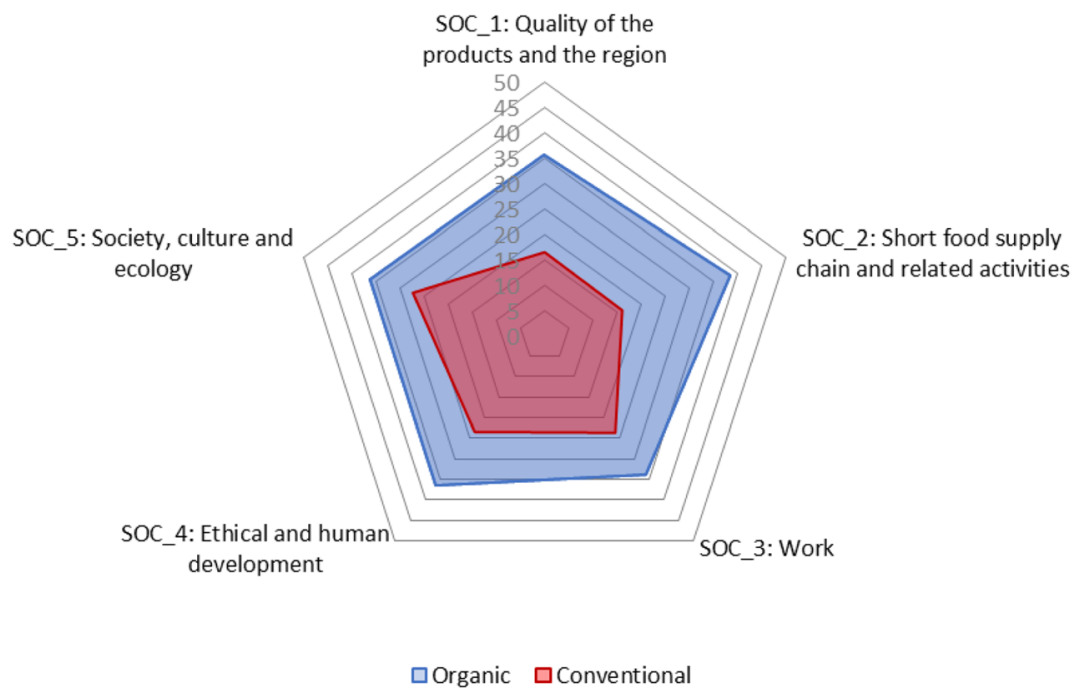

Fig. 5 Radar diagram of conventional vs organic farms' average performance 
achieved 29.5 out of 50 . This is probably because their product types are often sold to only a few large clients. On the contrary, pigs and especially poultry farms achieved the highest average values in almost all components, because of the diversification of production and income and the greater ability to offer sales services and other social functions. Similar results were noticed in the CS_3 component (work). This is probably due to the higher level of multifunctionality of these farms, rather than a greater demand for workers with livestock, that leads to a higher contribution to employment. On the other hand, the CS_4 (ethical and human development) and the CS_5 (society, culture and ecology) components are characterized by higher scores in the cattle, particularly for milk production, and the pig samples. This result is rather interesting and suggests the need for further evaluation. The fact that the high level of knowledge requested for these types of systems could also influence education and culture or that, traditionally, these farmers are more involved in innovation processes are only two of many potential interpretations.

Figure 4 shows the results of the farms, aggregated by land area classes. Only a few differences were noted. In particular, the CS_2 component seems to allow some relevant considerations; smaller farms tend to achieve higher results (22.9 out of 50) because of their predisposition to finding different types of income. The results of the CS_3 component (work) seems to not be influenced by the land area of the farms. In the literature, these results have contradictory feedbacks. Our data is in accord with that of Häni et al. 2003, which did not find any substantial difference in the corresponding social component (work condition) of the RISE method. On the other hand, it is in disaccord with Gavrilescu et al. 2012 who, applying the IDEA method, attributed lower scores to family farms compared to legal entities mostly because of their rigidity in creating new jobs, low professional training and a lower minimum wage. Reig-Martinez et al. 2011 found an overall high level of sustainability, even social, of larger farms that could be explained through the opportunity to develop a more diversified range of crops and the generation of sufficient income that has permitted the continuity of agricultural activity. It can be supposed that these great differences are probably due to the high dissimilarity of the samples involved in the studies.

Finally, in Fig. 5, the performances of conventional and organic farms are compared. The differences between the two types of production were considerable: organic farms achieved higher scores in every component. The result of the CS_1 component was expected, in consideration of the relevance of organic certification. The excellent results in the short chain and the related activities (CS_2) and work (CS_3) components are a direct consequence of their higher regard for multifunctionality. These aspects also involve the CS_4 and CS_5 components, as confirmation of the higher level of culture, education and training required for the practice of organic production.

\section{Discussion and conclusions}

A new method for the evaluation of the social sustainability of farms has been proposed. It provides easy-to-read results and information at different scales of interpretation. The method seems adequate to perform an evaluation of the social sustainability of agricultural activities allowing for different approaches, such as: 
1) Farm comparison by ranking of indicators and farm comparison by aggregate component ranking: the comparison among farms, or groups of farms, that seems to be useful for policy-makers to identify agriculturally sustainable practices and the farm features that influence social sustainability, such as the type of animal production, land area and multifunctional activities, individual and detailed aspects of sustainability, as well as a high variability of aspects aggregated together to a more comprehensive vision of the evaluation;

2) Single indicator evaluation: the evaluation of a single or few aspects of social sustainability is able to provide synthetic information to farmers who want to evaluate the level reached by their farm and to know the ways to improve by comparison with other farms;

3) Score evolution: the temporal comparison looks at the evolution of the results achieved by farms over time and those that are predictable in the future. This approach was not calculated in this research, because of the lack of farm data for different years, but it is still worth being cited because of its potential multiple utilizations. For example, farmers could use it to evaluate the trend of their own work, while policy-makers, comparing the performance of different farms systems over time, could obtain useful information for decision-making.

The assessment of social sustainability involves some relevant issues, considering that the current objectives of policy-makers are dedicated to the improvement of the environment and the landscape (e.g. Greening's conditions in the new Common Agricultural Policy) and the social value of agriculture (e.g. the Measures of the Rural Development Plan).

From a practical point of view, the social pillar often involves themes highly dependent on the farms' characteristics that still seem hard to measure because of the lack of a shared knowledge. Because of this, we believe we have shown an approach able to avoid the problems of qualitative assessments. Nevertheless, we point out the need for periodical revision of the method, in order to keep in step with the evolution of the social issues of the rural sector and improve the quantity and quality of information provided. For example, as the indicators used in the analysis relates specifically to social condition inside the farms, an interesting improvement may involve the direct assessment of social impact of farms' activities in their territories.

In addition, the study underlined that the integration of the method with assessments of environmental and economic performances could be a valid way to the validation of the social dimension. Because of its particular sensitivity to the local situation, a further approach might involve the comparison of the results of farms located in different geographical contexts.

\section{Endnotes}

${ }^{1}$ See Häni et al. (2003), Rasul and Thapa (2004), Van Cauwenbergh et al. (2007), Meul et al. (2008), Vilain et al. (2008), Zahm et al. (2008), Gómez-Limón and Fernandez (2010), Parachini et al. (2011), Bonneau et al. (2014). 


\section{Appendix}

Table 3 Framework: sub-indicators, indicators and dimensions

\begin{tabular}{|c|c|c|c|c|c|c|c|}
\hline Farm characteristic & Source & Code & Sub-indicator & $\begin{array}{l}\text { Score } \\
\text { range }\end{array}$ & Code & Indicator & $\begin{array}{l}\text { Max } \\
\text { score }\end{array}$ \\
\hline $\begin{array}{l}\text { Number of products } \\
\text { involved in quality certified } \\
\text { products }\end{array}$ & Questionnaire & S_1_a & $\begin{array}{l}\text { Quality certified } \\
\text { commodities }\end{array}$ & $0-\infty$ & S_1 & $\begin{array}{l}\text { Quality of } \\
\text { the products }\end{array}$ & 20 \\
\hline $\begin{array}{l}\text { Number of quality certified } \\
\text { products }\end{array}$ & Questionnaire & S_1_b & $\begin{array}{l}\text { Quality certified } \\
\text { food products }\end{array}$ & $0-\infty$ & & & \\
\hline $\begin{array}{l}\text { Number of vegetal organic } \\
\text { products }\end{array}$ & Questionnaire & S_1_C & $\begin{array}{l}\text { Vegetal organic } \\
\text { production }\end{array}$ & $0-\infty$ & & & \\
\hline $\begin{array}{l}\text { Number of animal organic } \\
\text { products }\end{array}$ & Questionnaire & S_1_d & $\begin{array}{l}\text { Animal organic } \\
\text { production }\end{array}$ & $0-\infty$ & & & \\
\hline $\begin{array}{l}\text { Aesthetics care of rural } \\
\text { buildings }\end{array}$ & Questionnaire & S_2_a & $\begin{array}{l}\text { Aesthetics of rural } \\
\text { buildings }\end{array}$ & $0-4$ & S_2 & $\begin{array}{l}\text { Rural } \\
\text { buildings }\end{array}$ & 12 \\
\hline $\begin{array}{l}\text { Maintenance of the original } \\
\text { use of the rural buildings }\end{array}$ & Questionnaire & S_2_b & $\begin{array}{l}\text { Maintenance of } \\
\text { the original use } \\
\text { of the rural } \\
\text { buildings }\end{array}$ & $0-4$ & & & \\
\hline $\begin{array}{l}\text { Number of buildings built or } \\
\text { renovate using "green } \\
\text { techniques" }\end{array}$ & Questionnaire & S_2_C & $\begin{array}{l}\text { Green building } \\
\text { techniques }\end{array}$ & $0-\infty$ & & & \\
\hline $\begin{array}{l}\text { Maintenance of the farm } \\
\text { green spaces }\end{array}$ & Questionnaire & S_3_a & $\begin{array}{l}\text { Green } \\
\text { maintenance }\end{array}$ & $0-4$ & S_3 & $\begin{array}{l}\text { Landscape } \\
\text { and territory }\end{array}$ & 18 \\
\hline $\begin{array}{l}\text { Presence of hedges, rows } \\
\text { and wooded bands }\end{array}$ & Questionnaire & S_3_b & $\begin{array}{l}\text { Hedges, rows and } \\
\text { wooded bands }\end{array}$ & $0-4$ & & & \\
\hline $\begin{array}{l}\text { Maintenance of the roads } \\
\text { and paths }\end{array}$ & Questionnaire & S_3_C & $\begin{array}{l}\text { Maintenance of } \\
\text { the roads and } \\
\text { paths }\end{array}$ & $0-4$ & & & \\
\hline $\begin{array}{l}\text { Number of crop species/UAA } \\
\text { (N/ha) }\end{array}$ & $\begin{array}{l}\text { SIARL } \\
\text { Database }\end{array}$ & S_3_d & $\begin{array}{l}\text { Crop } \\
\text { diversification }\end{array}$ & $0-6$ & & & \\
\hline $\begin{array}{l}\text { Selling through direct sale } \\
\text { (farm shop) }\end{array}$ & Questionnaire & S_4_a & Direct sales & $0-3$ & S_4 & $\begin{array}{l}\text { Short food } \\
\text { supply chain }\end{array}$ & 30 \\
\hline $\begin{array}{l}\text { Selling through online } \\
\text { website, portals, etc. }\end{array}$ & Questionnaire & S_4_b & Online sales & $0-1$ & & & \\
\hline $\begin{array}{l}\text { Income from short chain } \\
\text { channels/income from } \\
\text { conventional channels (\%) }\end{array}$ & Questionnaire & S_4_C & $\begin{array}{l}\text { Direct sales } \\
\text { relevance }\end{array}$ & $0-20$ & & & \\
\hline $\begin{array}{l}\text { Number of product sold } \\
\text { through direct sale channels }\end{array}$ & Questionnaire & S_4_d & $\begin{array}{l}\text { Product sold } \\
\text { through direct } \\
\text { sales }\end{array}$ & $0-\infty$ & & & \\
\hline $\begin{array}{l}\text { Sales through ethical } \\
\text { purchasing groups }\end{array}$ & Questionnaire & S_4_e & $\begin{array}{l}\text { Sales through } \\
\text { ethical } \\
\text { purchasing } \\
\text { groups }\end{array}$ & $0-3$ & & & \\
\hline $\begin{array}{l}\text { Sales through farmers' } \\
\text { markets }\end{array}$ & Questionnaire & S_4_f & $\begin{array}{l}\text { Sales through } \\
\text { farmers' markets }\end{array}$ & $0-2$ & & & \\
\hline Sales to restaurant and shops & Questionnaire & S_4_g & $\begin{array}{l}\text { Sales to } \\
\text { restaurant and } \\
\text { shops }\end{array}$ & $0-2$ & & & \\
\hline Sales to dining halls & Questionnaire & S_4_h & $\begin{array}{l}\text { Sales to dining } \\
\text { halls }\end{array}$ & $0-3$ & & & \\
\hline $\begin{array}{l}\text { Social services (e.g. snow } \\
\text { removal, composting, }\end{array}$ & Questionnaire & S_5_a & Social services & $0-2$ & S_5 & $\begin{array}{l}\text { Related } \\
\text { activities }\end{array}$ & 20 \\
\hline
\end{tabular}
public green areas) 
Table 3 Framework: sub-indicators, indicators and dimensions (Continued)

\begin{tabular}{|c|c|c|c|c|c|c|c|}
\hline $\begin{array}{l}\text { Type of related activities (e.g. } \\
\text { agritourism, B\&B, restaurant) }\end{array}$ & Questionnaire & S_5_b & $\begin{array}{l}\text { Type of related } \\
\text { activities }\end{array}$ & $0-10$ & & & \\
\hline Educational farm, teaching & Questionnaire & S_5_c & Educational farm & $0-5$ & & & \\
\hline $\begin{array}{l}\text { Presence of other social } \\
\text { activities (e.g. disadvantages } \\
\text { people, children, social } \\
\text { inclusion) }\end{array}$ & Questionnaire & S_5_d & Social activities & $0-5$ & & & \\
\hline $\begin{array}{l}\text { UAA/annual amount of work } \\
\text { (ha/h) }\end{array}$ & $\begin{array}{l}\text { SIARL } \\
\text { Database, } \\
\text { Questionnaire }\end{array}$ & S_6_a & $\begin{array}{l}\text { Annual Work Unit } \\
\text { (AWU) }\end{array}$ & $0-8$ & S_6 & Work & 25 \\
\hline $\begin{array}{l}\text { Number of new } \\
\text { employments (in the last } \\
5 \text { years) }\end{array}$ & Questionnaire & S_6_b & $\begin{array}{l}\text { New } \\
\text { employments }\end{array}$ & $0-\infty$ & & & \\
\hline $\begin{array}{l}\text { Number of farm products } \\
\text { processing }\end{array}$ & Questionnaire & S_6_C & $\begin{array}{l}\text { Farm products } \\
\text { processing }\end{array}$ & $0-\infty$ & & & \\
\hline $\begin{array}{l}\text { Number of workers who } \\
\text { resided in the farm buildings }\end{array}$ & Questionnaire & S_7_a & $\begin{array}{l}\text { Workers who } \\
\text { resides in the } \\
\text { farm buildings }\end{array}$ & $0-2$ & S_7 & $\begin{array}{l}\text { Sustainability } \\
\text { of the } \\
\text { employment }\end{array}$ & 15 \\
\hline $\begin{array}{l}\text { Number of local workers/ } \\
\text { total number of employee } \\
\text { (\%) }\end{array}$ & Questionnaire & S_7_b & Local workers & $0-1$ & & & \\
\hline $\begin{array}{l}\text { Number of female workers/ } \\
\text { total number of workers (\%) }\end{array}$ & Questionnaire & S_7_C & Female workers & $0-4$ & & & \\
\hline Age of the entrepreneur & Questionnaire & S_7_d & $\begin{array}{l}\text { Youth } \\
\text { entrepreneurship }\end{array}$ & $0-4$ & & & \\
\hline $\begin{array}{l}\text { Youth workers/total number } \\
\text { of workers }(\%)\end{array}$ & Questionnaire & S_7_e & $\begin{array}{l}\text { Youth } \\
\text { employment }\end{array}$ & $0-4$ & & & \\
\hline $\begin{array}{l}\text { Training courses for workers } \\
\text { formation }\end{array}$ & Questionnaire & S_8_a & Training courses & $0-\infty$ & S_8 & Training & 10 \\
\hline $\begin{array}{l}\text { Presence of trainees from } \\
\text { schools and universities }\end{array}$ & Questionnaire & S_8_b & Trainees & $0-2$ & & & \\
\hline $\begin{array}{l}\text { Training activities unfold in } \\
\text { farm }\end{array}$ & Questionnaire & S_8_C & $\begin{array}{l}\text { Training activities } \\
\text { unfold in the } \\
\text { farm }\end{array}$ & $0-2$ & & & \\
\hline $\begin{array}{l}\text { Employment of } \\
\text { disadvantaged people } \\
\text { among the workers }\end{array}$ & Questionnaire & S_8_d & $\begin{array}{l}\text { Disadvantaged } \\
\text { people hired }\end{array}$ & $0-5$ & & & \\
\hline $\begin{array}{l}\text { Number of animal species } \\
\text { bred }\end{array}$ & $\begin{array}{l}\text { SIARL } \\
\text { Database }\end{array}$ & S_9_a & Animal species & $0-\infty$ & S_9 & $\begin{array}{l}\text { Livestock } \\
\text { management }\end{array}$ & 25 \\
\hline $\begin{array}{l}\text { S_9_b1 Type of stable } \\
\text { S_9_b2 Management by } \\
\text { physiological phases } \\
\text { S_9_b3 Systems of } \\
\text { ventilation or heat reduction } \\
\text { S_9_b4 Quality/quantity } \\
\text { control of the feed } \\
\text { S_9_b5 Attendance at birth } \\
\text { S_9_b6 Systems of cleaning }\end{array}$ & Questionnaire & S_9_b & Cattle & $0-20$ & & & \\
\hline $\begin{array}{l}\text { S_9_c1 Type of flooring } \\
\text { S_9_c2 Systems of } \\
\text { ventilation or heat reduction } \\
\text { S_9_c3 Handling systems of } \\
\text { animals } \\
\text { S_9_c4 Presence of materials } \\
\text { of environmental enrichment }\end{array}$ & Questionnaire & S_9_C & Swine & $0-20$ & & & \\
\hline $\begin{array}{l}\text { S_9_d1 Type of stable } \\
\text { S_9_d2 Systems of } \\
\text { ventilation or heat reduction }\end{array}$ & Questionnaire & S_9_d & Poultry & $0-20$ & & & \\
\hline
\end{tabular}


Table 3 Framework: sub-indicators, indicators and dimensions (Continued)

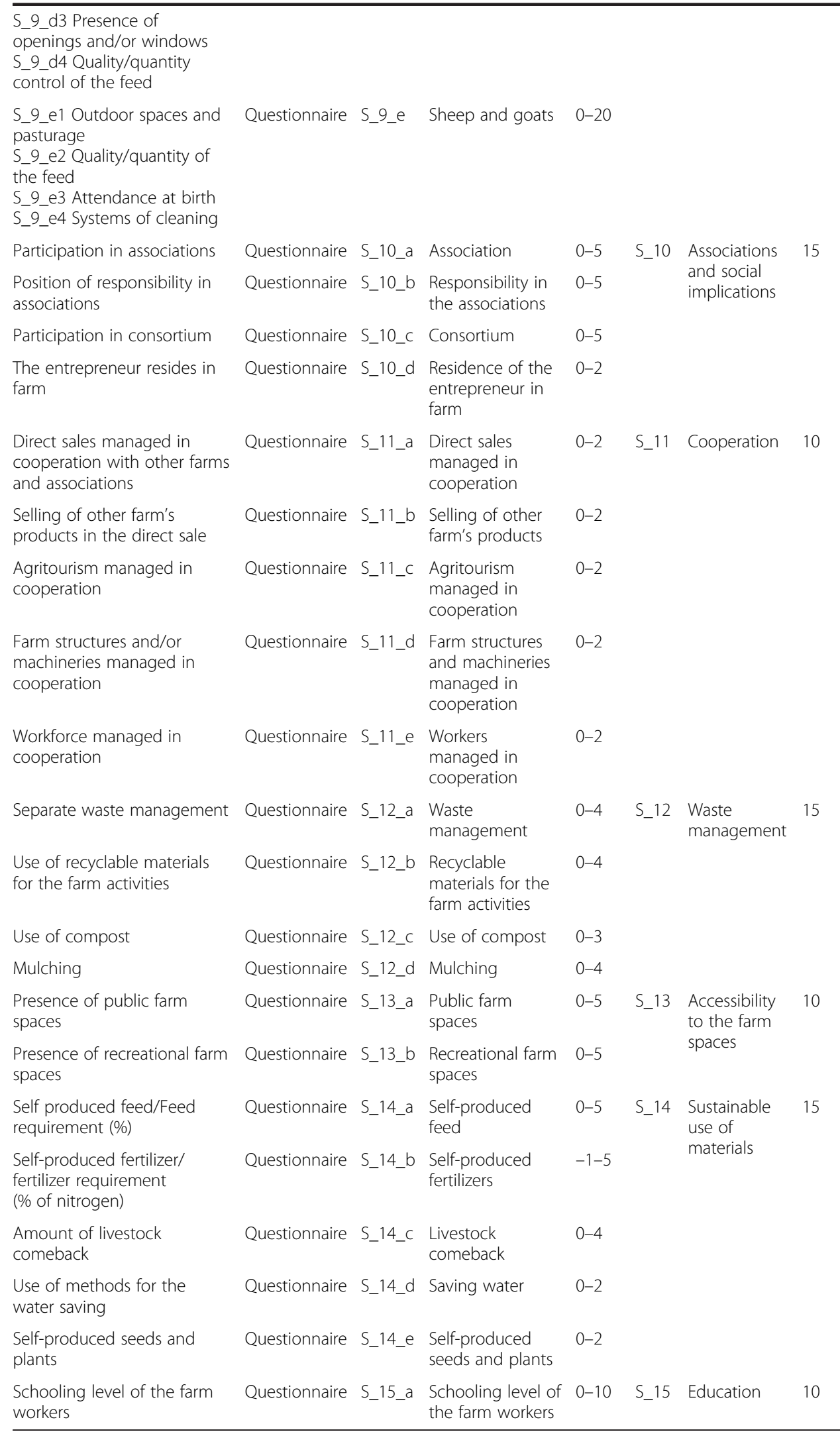




\section{Abbreviations}

PASM, Parco Agricolo Sud Milano, in English "South Milan Agricultural Park"; PDO, Protected Denomination of Origin SIARL, Sistema informativo Agricoltura Regione Lombardia

\section{Acknowledgements}

The authors would thank the Città Metropolitana di Milano, the Parco Agricolo Sud Milano and the Fondazione Cariplo for their support

\section{Authors' contributions}

This paper is the result of the contribution between all Authors. The "Background" section is attributable to AP, the "Method: Framework" to AG, the "Method: The components" to ED, "Method: Case study" to MEM, the "Results and discussion" to MB and the "Conclusion" to all authors. All authors read and approved the final manuscript.

\section{Authors' information}

AG is Associate Professor at the University of Milan (Department of Health, Animal Science and Food Safety, VESPA). MB is PhD student at the University of Milan (Department of Health, Animal Science and Food Safety, VESPA). MME is PhD student at the University of Milan (Department of Health, Animal Science and Food Safety, VESPA). ED is Researcher at the University of Milan (Department of Health, Animal Science and Food Safety (VESPA). AP is Full Professor at the University of Milan (Department of Health, Animal Science and Food Safety, VESPA).

\section{Competing interests}

This research was financed by the Fondazione Cariplo and it was supported by the Città Metropolitana di Milano and the Parco Agricolo Sud Milano.

Received: 30 October 2015 Accepted: 11 July 2016

Published online: 21 July 2016

\section{References}

Bessière J (1998) Local development and heritage: traditional food and cuisine as tourist attractions in rural areas. Sociol Rural 38(1):21-34

Bonneau M, Klauke TN, Gonzàlez J, Rydhmer L, llari-Antoine E, Dourmad JY, de Greef K, Houwers HWJ, Cinar MU, Fàbrega E, Zimmer C, Hviid M, van der Oever B, Edwards SA (2014) Evaluation of the sustainability of contrasted pig farming systems: integrated evaluation. Animal 8(12):2058-2068

Briquel V, Vilain L, Bourdais J-L, Girardin P, Mouchet C, Viaux P (2001) La méthode IDEA (indicateurs de durabilité des exploitations agricoles): une démarche pédagogique. Ingénieries EAT 25:29-39

Broom DM (2010) Animal welfare: an aspect of care, sustainability, and food quality required by the public. J Vet Med Educ 37(1):83-88

Chatzinikolaou P, Manos B (2012) Review of existing methodologies and tools for measuring sustainability in rural areas. http://www.feem-project.net/belpasso_2012/files/studpapers/Paper_Chatzinikolaou.pdf

Chinnici G, D'Amico M, Pecorino B (2002) A multivariate statistical analysis on the consumers of organic products. Br Food J 104(3/4/5):187-199

Demartini E, Gaviglio A, Bertoni D (2015) Integrating agricultural sustainability into policy planning: a geo-referenced framework based on rough set theory. Environ Sci Pol 54:226-239

Dimara E, Skuras D (2003) Consumer evaluations of product certification, geographic association and traceability in Greece. Eur J Mark 37(5/6):690-705

Elfkih S, Guldara I, Mtimet N (2012) Are Tunisian olive growing farms sustainable? An adopted IDEA approach analysis. Span J Agric Res 10(4):877-889

Falquera V, Aliguer N, Falguera M (2012) An integrated approach to current trends in food consumption: moving toward functional and organic products? Food Control 26(2):274-281

Fortun-Lamothe L, Combes S, Gidenne T (2009) Contribution of intensive rabbit breeding to sustainable development, a semi-quantitative analysis of the production in France. World Rabbit Sci 17:79-85

Fotopoulos C, Krystallis A (2002) Organic product avoidance: reasons for rejection and potential buyers' identification in a countrywide survey. Br Food J 104(3/4/5):233-260

Gafsi M, Favreau JL (2010) Appropriate method to assess the sustainability of organic farming systems. In: Proceedings of the 9th European IFSA Symposium, Vienna, 4-7 July 2010: 912-921.

Gaviglio A, Pirani A (2015) Consumer perception of cured pork meats: the added value of the organic attribute food analysis. Czech J Food Sci 33(1):32-36

Gaviglio A, Pirani A, Bertocchi M (2014a) Development of the environmental, social and economic sustainability in the periurban agricultural areas: governance opportunities in the South Milan Agricultural Park. Adv Eng Forum 11:417-423

Gaviglio A, Bertocchi M, Silvestri S, Pirani A (2014b) The use of environmental, economic and social indicators as decision support for the advancement of farms towards Sustainability. In: Sustainability of the agri-food system: strategies and performances. Proceedings of the 50th SIDEA conference, Lecce, 26-28 September 2013: 215-225.

Gaviglio A, Demartini E, Pirani A, Marescotti ME, Bertocchi M (2015b) National brands versus private labels versus niche products: a graphical representation of consumers' perception. Paper prepared for presentation at the EAAE-AAEA Joint Seminar 'Consumer Behavior in a Changing World: Food, Culture, Society. March 25 to 27, 2015 Naples, Italy.

Gavrilescu C, Toma C, Turtoi C (2012) Assessment of the sustainability of agricultural holdings in macroregion 1 using the IDEA method. Bulletin UASVM Horticulture 69(2):122-130

Girardin P, Bockstaller C, van der Werf HMG (1999) Indicators: tools to evaluate the environmental impacts of farming systems. J Sustain Agric 13:5-21

Gómez-Limón JA, Riesgo L (2009) Alternative approaches to the construction of a composite indicator of agricultural sustainability: an application to irrigated agriculture in the Duero basin in Spain. J Environ Manag 90(11):3345-3362 
Gómez-Limón JA, Sanchez-Fernandez G (2010) Empirical evaluation of agricultural sustainability using composite indicators. Ecol Econ 69(5):1062-1075

Hamm U, Gronefeld F (2004) The European market for organic food: revised and updated analysis, The European market for organic food: revised and updated analysis

Hand MS, Martinez S (2010) Just what does local mean. Choices 25(1):13-18

Häni F, Braga F, Stämpfli A, Keller T, Fisher M, Porche H (2003) RISE, a tool for holistic sustainability assessment at the farm level. Int Food Agribus Man Rev 6(4):78-90

Hansen JW (1996) Is agricultural sustainability a useful concept? Agric Syst 50(2):117-143

INEA (2014) L'agricoltura Lombardia Conta 2014. http://dspace.inea.it/handle/inea/1037

Jacobs M (1995) Sustainable development-from broad rhetoric to local reality. Conference Proceedings from Agenda 21 in Cheshire. Cheshire County Council, Document No. 493.

Kihlberg I, Risvik E (2007) Consumers of organic foods—value segments and liking of bread. Food Qual Prefer 18(3):471-481

Littig B, Griessler E (2005) Social sustainability: a catchword between political pragmatism and social theory. Int J Sustain Dev 8(1/2):65-79

Lockie S (2009) Responsibility and agency within alternative food networks: assembling the "citizen consumer". Agric Hum Values 26(3):193-201

Magnusson MK, Arvola A, Hursti UKK, Åberg L, Sjödén PO (2003) Choice of organic foods is related to perceived consequences for human health and to environmentally friendly behaviour. Appetite 40(2):109-117

Makatouni A (2002) What motivates consumers to buy organic food in the UK? Results from a qualitative study. Br Food J 104(3/4/5):345-352

Mazzocchi C, Sali G, Corsi S (2013) Land use conversion in metropolitan areas and the performance of agriculture: Sensitivity Index of Agricultural Land (SIAL), a tool for territorial analysis. Land Use Policy 35:155-162

Meul M, Van Passel S, Nevens F, Dessein J, Rogge E, Mulier A, Van Hauwermeiren A (2008) MOTIFS: a monitoring tool for the integrated farm sustainability. Agron Sustain Dev 28:321-332

Migliorini P, Scaltriti B (2012) Evaluation of sustainability of the farms in the Agricultural Park of South Milan and their production chain. Special issue New Medit 4:53-56

Omann I, Spangenberg JH (2002) Assessing social sustainability. The social dimension of sustainability in a socioeconomic Scenario. Presented at the 7th Biennial Conference of the International Society for Ecological Economics" in Sousse (Tunisia), 6-9 March 2002.

Pacini C, Giesen G, Wossink A, Omodei-Zorini L, Huirne R (2004) The EU's Agenda 2000 reform and the sustainability of organic farming in Tuscany: ecological-economic modelling at field and farm level. Agr Syst 80(2):171-197

Paracchini ML, Pacini C, Jones MLM, Pérez-Soba M (2011) An aggregation framework to link indicators associated with multifunctional land use to the stakeholder evaluation of policy options. Ecol Indic 11(1):71-80

Paracchini ML, Bulgheroni C, Borreani G, Tabacco E, Banterle A, Bertoni D, Rossi G, Parolo G, Origgi R, De Paola C (2015) A diagnostic system to assess sustainability at a farm level: The SOSTARE model. Agric Syst 133:35-53

Pieniak Z, Aertsens J, Verbeke W (2010) Subjective and objective knowledge as determinants of organic vegetables consumption. Food Qual Prefer 21(6):581-588

Platania M, Privitera D (2006) Typical products and consumer preferences: the 'soppressata' case. Br Food J 108(5):385-395

Rasul G, Thapa GB (2004) Sustainability of ecological and conventional agricultural systems in Bangladesh: an assessment based on environmental, economic and social perspectives. Agric Syst 79:327-351

Reig-Martınez E, Gómez-Limón JA, Picazo-Tadeo AJ (2011) Ranking farms with a composite indicator of sustainability. Agric Econ 42:561-575

Rigby D, Woodhouse P, Young T, Burton M (2001) Constructing a farm level indicator of sustainable agricultural practice. Ecol Econ 39:463-478

Santini F, Paloma SG (2013) Short food supply chains and local food systems in the EU: a state of play of their socio-economic characteristics, Publications Office

Seyfang G (2006) Ecological citizenship and sustainable consumption: examining local organic food networks. J Rural Stud 22(4):383-395

Singh RK, Murty HR, Gupta SK, Dikshit AK (2009) An overview of sustainability assessment methodologies. Ecol Indic 9(2):189-212

Smith CS, McDonald GT (1998) Assessing the sustainability of agriculture at the planning stage. J Environ Manag 52:15-37

Thiollet-Scholtus M, Bockstaller C (2015) Using indicators to assess the environmental impacts of wine growing activity: The INDIGO ${ }^{\oplus}$ method. Eur J Agron 62:13-25

Van Cauwenbergh N, Biala K, Bielders C, Brouckaert V, Franchois L, Garcia Cidad V, Hermy M, Mathijs E, Muys B, Reijnders J, Sauvenier X, Valckx J, Vanclooster M, Van der Veken B, Wauters E, Peeters A (2007) SAFE—a hierarchical framework for assessing the sustainability of agricultural systems. Agric Ecosyst Environ 120(2-4):229-242

Van Der Werf HMG, Petit J (2002) Evaluation of the environmental impact of agriculture at the farm level: a comparison and analysis of 12 indicator based methods. Agric Ecosyst Environ 93(1):131-145

Van Ittersum K, Meulenberg MT, Van Trijp H, Candel MJ (2007) Consumers' appreciation of regional certification labels: a Pan-European study. J Agric Econ 58(1):1-23

Vanhonacker F, Lengard V, Hersleth M, Verbeke W (2010) Profiling European traditional food consumers. Br Food J 112(8):871-886

Verbeke W, Pieniak Z, Guerrero L, Hersleth M (2012) Consumers' awareness and attitudinal determinants of European Union quality label use on traditional foods. Bio-based Appl Econ 1(2):213-229

Verlegh PW, Steenkamp JBE (1999) A review and meta-analysis of country-of-origin research. J Econ Psychol 20(5):521-546

Viglizzo EF, Frank F, Bernardos J, Buschiazzo DE, Cabo S (2006) A rapid method for assessing the environmental performance of commercial farms in the Pampas of Argentina. Environ Monit Assess 117:109-134

Vilain L (2008) La méthode IDEA. Edicagri éditions, France

Von Wiren-Lehr S (2001) Sustainability in agriculture-an evaluation of principal goals-oriented concepts to close the gap between theory and practice. Agric Ecosyst Environ 93:131-145

Wells S (2001) Pandora's seed: the unforeseen cost of civilization. Random House, New York, New York, USA 
Zahm F, Viaux P, Girardin P, Vilain L, Mouchet C (2008) Assessing farm sustainability with the IDEA method-from the concept of farm sustainability to case studies on French farms. Sustain Dev 16:271-281

Zanoli R, Naspetti S (2002) Consumer motivations in the purchase of organic food: a means end approach. Br Food J 104(8):643-653

Zimmerer KS, Bassett TJ (2003) Political ecology: an integrative approach to geography and environment-development studies. Guilford Press.

Submit your manuscript to a SpringerOpen ${ }^{\circ}$ journal and benefit from:

- Convenient online submission

- Rigorous peer review

- Immediate publication on acceptance

- Open access: articles freely available online

- High visibility within the field

Retaining the copyright to your article

Submit your next manuscript at $>$ springeropen.com 